\title{
Biodegradation of textile azo dyes by a facultative Staphylococcus arlettae strain VN-11 using a sequential microaerophilic/aerobic process
}

\author{
Franciscon Elisangela ${ }^{a}, *$, Zille Andrea ${ }^{b}$, Dias Guimaro Fabio ${ }^{a}$, Ragagnin de Menezes Cristiano ${ }^{a}$, \\ Durrant Lucia Regina ${ }^{a}$, Cavaco-Paulo Artur ${ }^{\mathrm{C}}$ \\ ${ }^{a}$ Campinas State University, Department of Food Science, 13083-970 Campinas, São Paulo, Brazil \\ b IBMC - Instituto de Biologia Molecular e Celular, Universidade do Porto, Portugal \\ ${ }^{\mathrm{c}}$ University of Minho, Department of Textile Engineering, 4800-058 Guimarães, Portugal
}

\section{A R T I C L E I N F O}

\section{Article history:}

Received 11 September 2008

Received in revised form

20 October 2008

Accepted 20 October 2008

Available online 12 December 2008

\section{Keywords:}

Azo dyes

Staphylococcus arlettae

Biodegradation

Textile effluents

Aromatic amines

\begin{abstract}
A B S T R A C T
A facultative Staphylococcus arlettae bacterium, isolated from an activated sludge process in a textile industry, was able to successfully decolourize four different azo dyes under microaerophilic conditions (decolourization percentage $>97 \%$ ). Further aeration of the decolourized effluent was performed to promote oxidation of the degradation products. The degradation products were characterized by FT-IR and UV-vis techniques and their toxicity with respect to Daphnia magna was measured. The amine concentrations as well as the total organic carbon (TOC) levels were monitored during the biodegradation process. The presence of aromatic amine in the microaerophilic stage and its absence in the aerobic stage indicated the presence of azoreductase activity and an oxidative biodegradation process, respectively. TOC reduction was $\sim 15 \%$ in the microaerophilic stage and $\sim 70 \%$ in the aerobic stage. The results provided evidence that, using a single Staphylococcus arlettae strain in the same bioreactor, the sequential microaerophilic/aerobic stages were able to form aromatic amines by reductive break-down of the azo bond and to oxidize them into non-toxic metabolites.
\end{abstract}

(C) 2008 Elsevier Ltd. All rights reserved.

\section{Introduction}

Azo dyes, which are aromatic compounds with one or more $(-\mathrm{N}=\mathrm{N}-)$ groups, are the most important and largest class of synthetic dyes used in commercial applications (Vandevivere et al., 1998). They are considered as xenobiotic compounds that are very recalcitrant to biodegradation processes (Zollinger, 1991; Stolz, 2001). The textile industry accounts for two-thirds of the total dyestuff market. During the dyeing process, approximately $10-15 \%$ of the dyes used are released into the wastewater. The presences of these dyes in the aqueous ecosystem are the cause of serious environmental and health concerns (Fang et al., 2004; Asad et al., 2007). Several methods are used to treat textile effluents to achieve decolourization. These include physicochemical methods such as filtration, coagulation, carbon activated and chemical flocculation (Gogate and Pandit, 2004a, b). These methods are effective but they are expensive and involve the formation of a concentrated sludge that creates a secondary disposal problem (Maier et al., 2004). In recent years, new biological processes, including aerobic and anaerobic bacteria and fungi, for dye degradation and wastewater reutilization have been developed.

\footnotetext{
* Corresponding author. Tel.: +55 193521 2173; fax: +55 1935212153

E-mail address: elisfran@fea.unicamp.br (F. Elisangela).
}

The most widely researched fungi in regard to dye degradation are the ligninolytic fungi (Bumpus, 2004). White-rot fungi in particular produce lignin peroxidase, manganese-peroxidase and laccase that degrade many aromatic compounds due to their nonspecific enzyme systems (Stolz, 2001; Robinson et al., 2001; McMullan et al., 2001; Wesenberg et al., 2003; Forgacs et al., 2004; Harazono and Nakamura, 2005; Pazarlioglu et al., 2005; Toh et al., 2003; Mohorcic et al., 2006; Madhavi et al., 2007). Large literature exists regarding the potential of these fungi to oxidize phenolic, nonphenolic, soluble and non-soluble dyes (Field et al., 1993; PastiGrigsby et al., 1992; Bumpus, 1995; Conneely et al., 1999; Kapdan et al., 2000; Borchert and Libra, 2001; Tekere et al., 2001; Kapdan and Kargi, 2002; Martins et al., 2002; Libra et al., 2003). Laccase preparations obtained from Pleurotus ostreatus, Schizophyllum commune, Sclerotium rolfsii and Neurospora crassa, increased up to $25 \%$ the decolourization of individual commercial triarylmethane, anthraquinonic, and indigoid textile dyes (Abadulla et al., 2000). In contrast, manganese peroxidase was reported as the main enzyme involved in dye decolourization by Phanerochaete chrysosporium (Chagas and Durrant, 2001) and lignin peroxidase for Bjerkandera adusta (Robinson et al., 2001). Some non-white-rot fungi that can successfully decolourize dyes have also been reported (Kim and Shoda, 1999; Cha et al., 2001; Ambrósio and Campos-Takaki, 2004; Bumpus, 2004; Tetsch et al., 2005). However, the long growth cycle 
and the complexity of the textile effluents, which are extremely variable in composition, limit the performance of these fungi. Although stable operation of continuous fungal bioreactors for the treatment of synthetic dye solutions has been achieved, application of white-rot fungi for the removal of dyes from textile wastewaters faces many problems such as large volumes produced, the nature of synthetic dyes, and control of biomass (Palma et al., 1999; Nigam et al., 2000; Zhang and Yu, 2000; Robinson et al., 2001; Mielgo et al., 2001; Stolz, 2001). In contrast, the bacterial reduction of the azo bond is usually nonspecific and bacterial decolourization is normally faster. Microbial decolourization and degradation has appeared as an environmentally friendly and cost-competitive alternative to chemical decomposition processes (Verma and Madamwar, 2003; Moosvi et al., 2005; Pandey et al., 2007; Whiteley, 2007; Khalid et al., 2008; Dhanve et al., 2008; Ozdemir et al., 2008). Research on bacterial strains that are able to decolourize azo dyes under aerobic (Xenphylus azovorans KF46F, Bacillus strain, Kerstersia sp. strain VKY1 and Staphylococcus sp.) and anaerobic conditions (Sphingomonas xenophaga BN6, Eubacterium sp., Clostridium sp., Butyrvibrio sp. or Bacteroides sp.) have been extensively reported (Rafii et al., 1990; Kudlich et al., 1997; Suzuki et al., 2001; Blumel et al., 2002; Olukanni et al., 2006; Dos Santos et al., 2007; Vijaykumar et al., 2007; Hsueh and Chen, 2008; Lin and Leu, 2008). Based on the available literature, it can be concluded that the microbial decolourization of azo dyes is more effective under anaerobic conditions. On the other hand, these conditions lead to aromatic amine formation, and these are mutagenic and toxic to humans (Chung and Stevens, 1993; Do et al., 2002; Pinheiro et al., 2004) requiring a subsequent oxidative (aerobic) stage for their degradation. In this context, the combined anaerobic/ aerobic biological treatments of textile dye effluents using microbial consortia are common in the literature (Chang and Lin, 2000; Van der Zee and Villaverde, 2005; Lodato et al., 2007). However, few commercial or industrial applications have been developed using a single adaptable microorganism in a sequential anaerobic/aerobic treatment (Isik and Sponza, 2003; Isik and Sponza, 2004; Supaka et al., 2004). Moreover, the available literature on the sequential microaerophilic/aerobic treatment with a single microorganism is extremely limited (Sandhya et al., 2004; Xu et al., 2007). Apparently there is a need to develop novel biological decolourization processes leading to the more effective clean up of azo dyes using a single microorganism that is efficient under both anaerobic/microaerophilic and aerobic conditions. Thus the main objective of this study was to observe the degradation of four azo dyes in a successive microaerophilic/aerobic process using exclusively a facultative anaerobic Staphylococcus arlettae bacterium isolated from textile dye effluents. Dye degradation was performed under microaerophilic conditions until no residual colour was observed. The medium was subsequently aerated by stirring to promote oxidation of the aromatic amines formed by the reductive break-down of the azo bond into non-toxic metabolites. The effects of sodium pyruvate and yeast extract as carbon sources on the decolourization were also investigated, since it has been reported that the type of carbon source could affect dye decolourization and its subsequent reduction (Nigam et al., 1996; Brás et al., 2001; Kim et al., 2008). The amine concentrations and TOC were monitored during the biodegradation process. The degradation products were also characterized using FT-IR and UV-vis techniques, and their toxicity measured.

\section{Materials and methods}

\subsection{Chemicals and media}

The azo dyes (100 $\mathrm{mg} \mathrm{L}^{-1}$ ) CI Reactive Yellow 107 (RY107, $0.18 \mathrm{mM}$ ), CI Reactive Black 5 (RB5, $0.11 \mathrm{mM}$ ), CI Reactive Red 198 (RR198, $0.13 \mathrm{mM}$ ) and CI Direct Blue 71 (DB71, $0.1 \mathrm{mM}$ ) were kindly provided by the Vicunha Textile Company, Itatiba, Brazil. The structures of the dyes are shown in Fig. 1. All other analytical grade reagents were purchased from Sigma and used without further purification. The mineral salts medium (MM) at $\mathrm{pH} 7$ used in all the batch experiments contained: $\mathrm{K}_{2} \mathrm{HPO}_{4}\left(1.6 \mathrm{~g} \mathrm{~L}^{-1}\right), \mathrm{KH}_{2} \mathrm{PO}_{4}(0.2 \mathrm{~g}$ $\left.\mathrm{L}^{-1}\right),\left(\mathrm{NH}_{4}\right)_{2} \mathrm{SO}_{4}\left(1.0 \mathrm{~g} \mathrm{~L}^{-1}\right), \mathrm{MgSO}_{4} \cdot 7 \mathrm{H}_{2} \mathrm{O}\left(0.2 \mathrm{~g} \mathrm{~L}^{-1}\right), \mathrm{FeSO}_{4} \cdot 7 \mathrm{H}_{2} \mathrm{O}$ (0.01 $\left.\mathrm{g} \mathrm{L}^{-1}\right), \mathrm{NaCl}\left(0.1 \mathrm{~g} \mathrm{~L}^{-1}\right), \mathrm{CaCl}_{2} \cdot 2 \mathrm{H}_{2} \mathrm{O}\left(0.02 \mathrm{~g} \mathrm{~L}^{-1}\right)$. The rich mineral medium (MMR) consisted of MM supplemented with $100 \mathrm{mg} \mathrm{L}^{-1}$ of each dye, $3 \mathrm{~g} \mathrm{~L}^{-1}$ of glucose and $1 \mathrm{~g} \mathrm{~L}^{-1}$ of yeast extract and was autoclaved at $121{ }^{\circ} \mathrm{C}$ for $15 \mathrm{~min}$.

\subsection{Strain isolation and characterization}

The microorganisms were isolated from different stages of the activated sludge produced by the Vicunha Textile Company, Itatiba, Brazil. Serial dilutions $\left(10^{-1}-10^{-6}\right)$ of the samples collected were inoculated into nutrient agar medium by the spread plate technique. Isolated strains were inoculated into MM with a low glucose concentration $\left(0.1 \mathrm{~g} \mathrm{~L}^{-1}\right)$ and mixed with azo dyes $\left(100 \mathrm{mg} \mathrm{L}^{-1}\right.$ per dye) and incubated under microaerophilic conditions at $30^{\circ} \mathrm{C}$ for 7 days. The strain that achieved the best decolourization was selected for this study.

Identification of the isolated strain was performed by $16 \mathrm{~S}$ rDNA sequence analysis. Genomic DNA was obtained according to Pitcher et al. (1989). The 16SrRNA gene was amplified by PCR using the specific primers, $27 \mathrm{f}$ and $1401 \mathrm{r}$ for the universal bacteria domain (Lane, 1991).

Fifty-microlitre reaction mixtures were prepared containing $100 \mathrm{ng}$ of total DNA, $2 \mathrm{U}$ of Taq polymerase (Invitrogen ${ }^{\circledR}$ ), $0.2 \mathrm{mM}$ of deoxynucleoside triphosphates and $0.4 \mu \mathrm{M}$ of each primer. The PCR amplifications were done using an initial denaturation step of 2 min at $94^{\circ} \mathrm{C}$, followed by 10 cycles of 1 min each at $94^{\circ} \mathrm{C}, 30 \mathrm{~s}$ at $69{ }^{\circ} \mathrm{C}$, decreasing $0.5^{\circ} \mathrm{C}$ each cycle, and $3 \mathrm{~min}$ at $72{ }^{\circ} \mathrm{C}$, followed by another 10 cycles of $1 \mathrm{~min}$ each at $94^{\circ} \mathrm{C}, 30 \mathrm{~s}$ at $63^{\circ} \mathrm{C}$ and $3 \mathrm{~min}$ at $72{ }^{\circ} \mathrm{C}$, in an Eppendorf thermal cycler.

The PCR product was purified on GFX ${ }^{\mathrm{TM}}$ PCR DNA and a Gel Band Purification kit (GE HealthCare) for automated sequencing in the MegaBace DNA Analysis System 1000. The sequencing was carried out using the $10 \mathrm{f}\left(5^{\prime} \mathrm{GAG}\right.$ TTT GAT CCT GGC TCA G3'); $765 \mathrm{f}$ ( $5^{\prime}$ ATT AGA TAC CCT GGT AG3'); 782r (5'ACC AGG GTA TCT AAT CCT GT3') and 1100r ( $5^{\prime}$ AGG GTT GGG GTG GTT G $3^{\prime}$ ) primers and the DYEnamic ET Dye Terminator Cycle Sequencing Kit for the automated MegaBace 500 system (GE Healthcare), according to the manufacturer's instructions.

Partial 16S rRNA sequences obtained from isolates were assembled in a contig using the phred/Phrap/CONSED program (Godon et al., 1997; Ewing et al., 1998). Identification was achieved by comparing the contiguous $16 \mathrm{~S}$ rRNA sequences obtained with the 16S rRNA sequence data from the reference and type strains available in the public databases GenBank and RDP (Ribosomal Database Project, Wisconsin, USA) using the BLASTn and RDP sequence match routines, respectively. The sequences were aligned using the CLUSTAL X program and analyzed with the MEGA software 2001 (Thompson et al., 1994; Kumar et al., 2004). Evolutionary distances were derived from sequence-pair dissimilarities, calculated as implemented in MEGA, using Kimura's DNA substitution model (Kimura, 1980).

The phylogenetic reconstruction was done using the neighbourjoining (NJ) algorithm, with bootstrap values calculated from 1000 replicate runs, using the routines included in the MEGA software (Saitou and Nei, 1987).

\subsection{Aromatic amine detection}

The aromatic amines in the solid phase were determined by the modified Marik and Lam method (2003). Samples were taken after 
<smiles>CC(=O)Nc1cc(N)c(S(=O)(=O)O[Na])cc1N=Nc1ccc(S(=O)(=O)O[Na])cc1</smiles>

\section{C.I. Reactive Yellow 107 (RY107)}<smiles>Cc1ccccc1Nc1nc(Cl)nc(Nc2cc(S(=O)(=O)O)cc3cc([S+]([O])([O-])O[Na])c(N=Nc4ccccc4S(=O)(=O)[O-])c(O)c23)n1</smiles>

\section{C.I. Reactive Red 198 (RR198)}<smiles>Nc1c(/N=N/c2ccc(S(=O)(=O)OCCS(=O)(=O)O)cc2)c(S(=O)(=O)O)cc2cc(S(=O)(=O)O)c(N=Nc3ccc(S(=O)(=O)O)cc3)c(O)c12</smiles>

\section{C.I. Reactive Black 5 (RB5)}

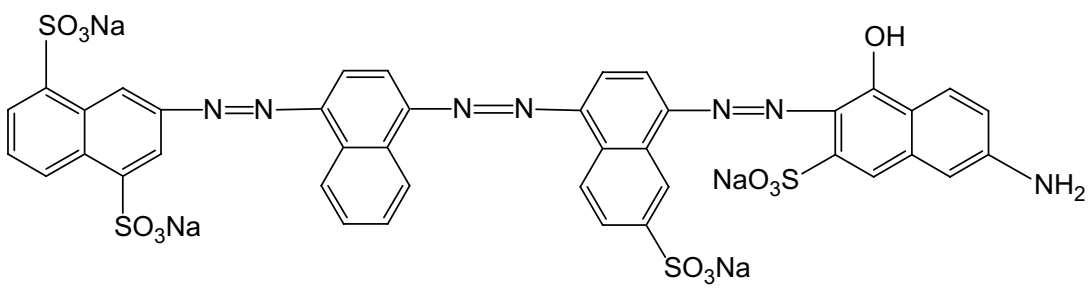

\section{C.I. Direct Blue 71 (DB71)}

Fig. 1. Chemical dye structures.

incubation under the microaerophilic and aerobic conditions, frozen and freeze-dried (FTS system model Dura-Dry MP). The samples ( $5 \mathrm{mg}$ ) were dissolved in $5 \mathrm{~mL}$ of a $0.4 \%$ solution of chloranil in dimethylformamide (DMF) and heated to $100{ }^{\circ} \mathrm{C}$ for $5 \mathrm{~min}$. The absorption was determined in a UV-vis Helios $\alpha$ Unicam spectrophotometer at $560 \mathrm{~nm}$. A calibration curve was prepared using aniline-2-sulfonic acid as a model product of the reduction of azo dyes, and the sample amine concentration was calculated in millimoles $\mathrm{L}^{-1}$. The control was the MMR medium without the dye, treated with the bacterium under microaerophilic and aerobic conditions.

\subsection{Dye decolourization}

Decolourization assays were carried out under static conditions with $350 \mathrm{~mL}$ cultures of MMR (pH 7) supplemented with $100 \mathrm{mg}$ $\mathrm{L}^{-1}$ of the dyes. The samples were incubated under microaerophilic conditions at $30^{\circ} \mathrm{C}$ for $168 \mathrm{~h}$ or until no colour was observed. Further aeration was carried out in a shaker at $150 \mathrm{rpm}$ to promote oxidation of the degradation products. Dye decolourization was measured in a UV-visible spectrophotometer (Shimadzu 2101) for the microaerophilic and aerobic stages, and the percentage of effluent decolourization was calculated.

\subsection{UV-vis analysis}

The dye degradation products produced during biodegradation under microaerophilic and aerobic conditions were studied by following the change in the UV-vis spectra (from 200 to $800 \mathrm{~nm}$ ) using a UV-vis spectrophotometer (Agilent 8453).

\subsection{Infrared spectrum analysis}

The controls and samples were dried and mixed with $\operatorname{KBr}(1: 20$; $0.02 \mathrm{~g}$ of sample with $\mathrm{KBr}$ at a final weight of $0.4 \mathrm{~g}$ ). The samples were then ground, desorbed at $60^{\circ} \mathrm{C}$ for $24 \mathrm{~h}$ and pressed to obtain IR-transparent pellets. The absorbance FT-IR spectra of the samples were recorded using an FT-IR Spectrum 2000 Perkin-Elmer spectrometer. The spectra were collected within a scanning range of $400-4000 \mathrm{~cm}^{-1}$. The FT-IR was first calibrated for background signal scanning with a control sample of pure $\mathrm{KBr}$, and then the experimental sample was scanned. The FT-IR spectrum of the 
control was finally subtracted from the spectra of the non-degraded and degraded dyes.

\subsection{TOC measurement}

The presence of organic carbon in the samples containing dyes was monitored by measuring the total organic carbon (TOC) under microaerophilic conditions and after agitation, using a TOC analyzer (Shimadzu 5000A) with automatic injection of the samples (500-2000 $\mu$ L) (Shimadzu Corporation, 1997). Samples were centrifuged $(20,000 \times g$ for $15 \mathrm{~min})$ and filtered through a $0.45-\mu \mathrm{m}$ pore size filter. The TOC measurement is based on the combustion of the total carbon (TC) on a sample filled tube with a catalyst and heated to $680^{\circ} \mathrm{C}$. The standard deviation is less than $2 \%$ for full scale ranging from $2000 \mathrm{ppm}$ to $4000 \mathrm{ppm}$. All the samples were analysed using a five-point calibration curve.

\subsection{Toxicity test}

After treatment with Staphylococcus arlettae, the samples were centrifuged at $20,000 \times g$ for $20 \mathrm{~min}$ and filtered through a $0.45-\mu \mathrm{m}$ pore size filter. The acute toxicity tests with Daphnia magna (Crustacea, Cladocera) were carried out according to the ABNT NBR 12713 methodology (1993). The sensitivity tests were carried out with neonates (6-24 h old). For each sample concentration $(1,25$, $50,75,100 \%), 5$ organisms were used in a $5 \mathrm{~mL}$ flask. The tests under the microaerophilic and aerobic conditions and the control in water were carried out in triplicate for each concentration. The flasks containing the samples were maintained at $20^{\circ} \mathrm{C}$ for $48 \mathrm{~h}$ in the absence of light. The number of immobile organisms was then counted after $20 \mathrm{~s}$ of light exposure.

\section{Results}

\subsection{Strain isolation and identification}

The Staphylococcus arlettae strain VN-11 is a gram positive coccus, non-motile and facultative anaerobic bacterium. Heterotrophic bacteria, such as Staphylococcus sp., are usually dominant in the activated sludge system, degrading and eventually mineralizing organic compounds to carbon dioxide and water (Sidat et al., 1999; Ajibola et al., 2005; Olukanni et al., 2006).The VN-11 strain was isolated from raw effluents from a textile industry in Campinas, Brazil, and selected based on its ability to discolour a mixture of four azo dyes (100 $\mathrm{mg} \mathrm{L}^{-1}$ each) in a study in MM supplemented with a low glucose concentration $\left(0.1 \mathrm{~g} \mathrm{~L}^{-1}\right)$. The $16 \mathrm{~S}$ rRNA gene sequence of the $\mathrm{VN}-11$ strain was determined and compared with available $16 \mathrm{~S}$ rRNA gene sequences from organisms in the GenBank and RDP databases. The VN-11 strain was phylogenetically positioned in the genus Staphylococcus. The nucleotide alignment of the strain VN-11 supported bootstrap values of $99 \%$ similarity to Staphylococcus arlettae and other strains including the sequence of the strain types S. gallinarum ATCC $35539^{\mathrm{T}}$, S. cohnii, ATCC $29974^{\mathrm{T}}$ (D83361). The evolutive distance was based on the Kimura 2p model (Kimura, 1980). The GenBank accession numbers are represented in parentheses. Sulfobacillus acidophilus DSM $10332^{\mathrm{T}}$ was used as the outgroup. The phylogenetic tree (Fig. 2) showed the grouping of VN-11 within Staphylococcus arlettae, confirming its identification due to the high bootstrap value.

\subsection{Decolourization}

The strain Staphylococcus arlettae was tested to separately decolourize four azo dyes (CI Reactive Yellow 107, CI Reactive Red 198, CI Reactive Black 5 and CI Direct Blue 71) in a microaerophilic/aerated sequential process. Complete decolourization (>97\%, Table 1 ) of the azo dyes was achieved in the microaerophilic stage, even if the bacteria showed little growth (data not shown), and no significant changes were detected in the following aerobic stage. Staphylococcus arlettae could only decolourize the dyes effectively when the medium was supplemented with yeast extract. The decolourization time showed a relationship with the chemical structure of the dyes. The monoazo RY107 and RR198 were decolourized in 12 and $10 \mathrm{~h}$, respectively. The diazo RB5 and the triazo DB71 were decolourized after 24 and $48 \mathrm{~h}$, respectively (Table1).

\subsection{Aromatic amine determination}

All the decolourized dye media showed the presence of aromatic amines after the microaerophilic stage, with the exception of DB71. In this latter case the measurement could not be carried out, due to interference by the chemical structure of this dye with the methodology used (Table 1). The monoazos RY107 and RR198 showed amine concentrations of 0.21 and $0.13 \mathrm{mM}$, respectively. The diazo RB5 showed the highest amine concentration $(0.28 \mathrm{mM})$. After the aerobic stage a significant reduction in the amine concentrations was observed (Table 1 ). The mass balance of the azo dyes (\%), with the exception of DB71, was estimated from the amine concentrations after the microaerophilic dye degradation, assuming that that 1 mole of RY107 and RR198 should produce 2 moles of amines and that 1 mole of RB5 should produce 3 moles of amines (Nam and Tratnyek, 2000). The monoazo RY107 and RR198 achieved a 58\% and $100 \%$ of mass balance, respectively. The

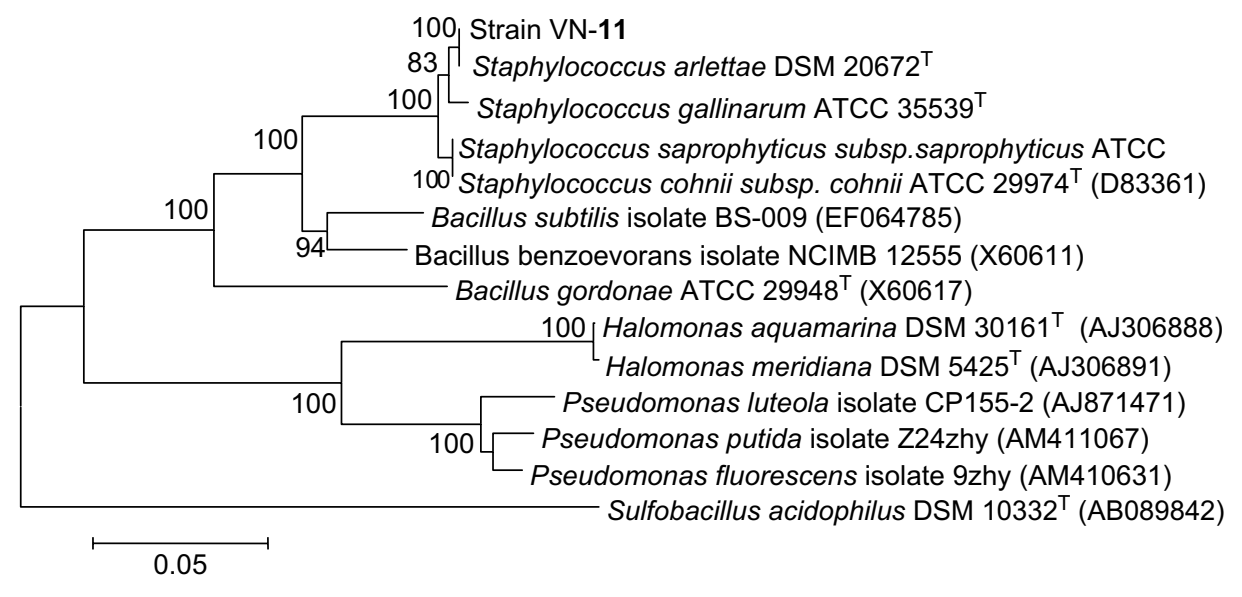

Fig. 2. Phylogenetic tree of Staphylococcus arlettae strain VN-11 for the partial sequences based on 16 rDNA. 
Table 1

Amine concentrations $(\mathrm{mM}) \pm \mathrm{SD}$, decolourization times $(\mathrm{h}) \pm \mathrm{SD}$ and decolourization (\%) $\pm \mathrm{SD}$ in solutions incubated with Staphylococcus arlettae under microaerophilic and aerobic conditions in the presence of azo dyes

\begin{tabular}{|c|c|c|c|c|c|}
\hline \multirow[t]{2}{*}{ Dyes } & \multirow{2}{*}{$\begin{array}{l}\text { Amine } \\
\text { concentration } \\
(\mathrm{mM})\end{array}$} & \multicolumn{2}{|c|}{ Decolourization time (h) } & \multicolumn{2}{|c|}{ Decolourization (\%) } \\
\hline & & Aerobic & Microaerophilic & Microaerophilic & Aerobic \\
\hline$\overline{\text { RY107 }}$ & $0.21 \pm 0.02$ & $0.01 \pm 0.02$ & $12 \pm 2$ & $98.5 \pm 0.5$ & $99.5 \pm 0.36$ \\
\hline RB5 & $0.28 \pm 0.02$ & $0.01 \pm 0.03$ & $24 \pm 3$ & $100 \pm 0.11$ & $98.9 \pm 0.26$ \\
\hline RR198 & $0.13 \pm 0.05$ & $0.04 \pm 0.03$ & $10 \pm 2$ & $97.7 \pm 0.5$ & $98 \pm 0.2$ \\
\hline DB71 & n.d. & n.d. & $48 \pm 4$ & $99 \pm 0.2$ & $96.3 \pm 0.5$ \\
\hline
\end{tabular}

diazo RB5, which is known as one of the most recalcitrant dyes, achieved only a $40 \%$ of mass balance.

\subsection{UV-vis characterization}

The biodegradation of the four azo dyes was monitored by UVvis analysis. For untreated dyes, as shown in Fig. 3a, RY107 presented two absorbance peaks at 301 and $550 \mathrm{~nm}$. As shown in Fig. 3b, RR198 presented absorbance peaks at 513, 380, 290 and $220 \mathrm{~nm}$ and a shoulder at $325 \mathrm{~nm}$. Fig. 3c shows that RB5 presented large peaks at 580 and $314 \mathrm{~nm}$. Two additional peaks with low absorbance were observed at 220 and $390 \mathrm{~nm}$. As shown in Fig. 3d, DB71 presented one large peak at $412 \mathrm{~nm}$ and a smaller peak at $300 \mathrm{~nm}$. Wide band absorption near $220 \mathrm{~nm}$ was observed for all the dyes. For treated dyes, after biodegradation of the four azo dyes in the microaerophilic and aerobic treated solutions, the absorbance peaks in the visible region disappeared, indicating complete decolourization. In the UV spectra, the peaks at 285 and $320 \mathrm{~nm}$ disappeared and were replaced by new peaks at 245 and $260 \mathrm{~nm}$ (Fig. 3).

\subsection{FT-IR characterization}

The FT-IR spectra obtained from the untreated dye samples showed several peaks in the region where $\mathrm{N}-\mathrm{H}$ and $\mathrm{O}-\mathrm{H}$ stretching is normally observed $\left(3300-3500 \mathrm{~cm}^{-1}\right)$. After the microaerophilic and aerobic treatments a significant reduction in absorption was observed in this region. Other bands located in the range from $1610-1630 \mathrm{~cm}^{-1}$ and at $1402 \mathrm{~cm}^{-1}$ disappeared in the microaerophilic stage after reductive treatment. Moreover, in the microaerophilic stage two new bands were observed in the carbonyl region at around $1680-1600 \mathrm{~cm}^{-1}$, attributed to amine groups. These two bands disappeared in the aerobic stage and a new peak around $1680 \mathrm{~cm}^{-1}$ was observed. In the aerated samples a new broad region between 2400 and $2500 \mathrm{~cm}^{-1}$, associated with carboxylic acid and $\mathrm{NH}_{3}^{+}$ions, and new peaks at $850,950 \mathrm{~cm}^{-1}$ and $1140 \mathrm{~cm}^{-1}$, were observed (Fig. 4).

\subsection{Toxicity test and TOC reduction}

The results for Daphnia magna toxicity are presented as the percentage of death occurring in the solutions produced during the incubation of Staphylococcus arlettae under microaerophilic and aerobic conditions, as compared to the control composed of the dye solution and the culture medium without the bacterium. The tests were carried out in a 1:4 dilution of the original supernatant concentration, since $100 \%$ mortality occurred in the original and 1:2 supernatant concentrations. The controls showed equal mortality for all the dyes (40-47\%). Under microaerophilic conditions, mortality decreased for all the dyes and when the samples were
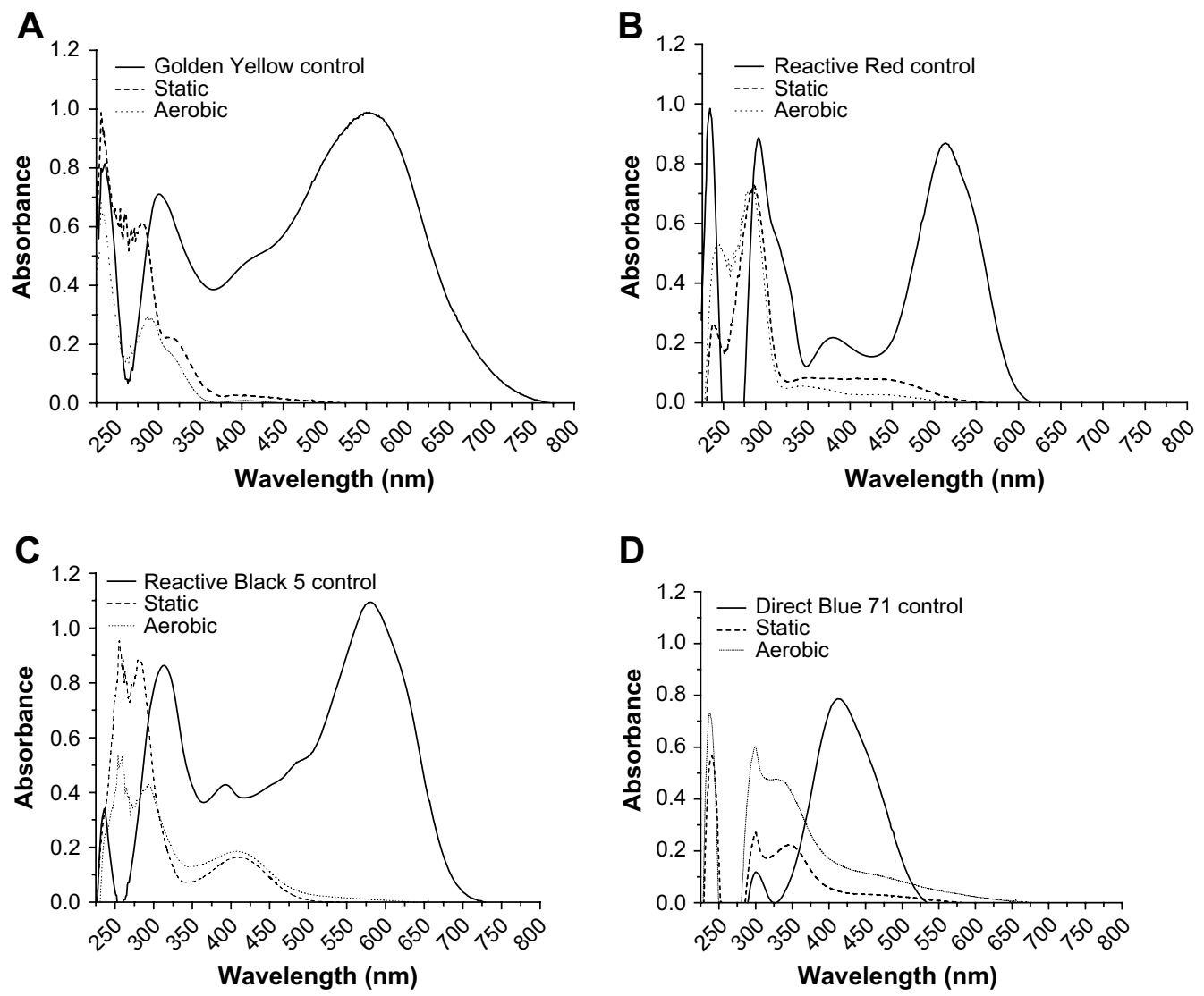

Fig. 3. UV-vis spectra of the azo dyes before (straight line) and after microaerophilic (dashed line) and aerobic (dotted line) treatments: (A) RY107, (B) RR198, (C) RB5, (D) DB71. 


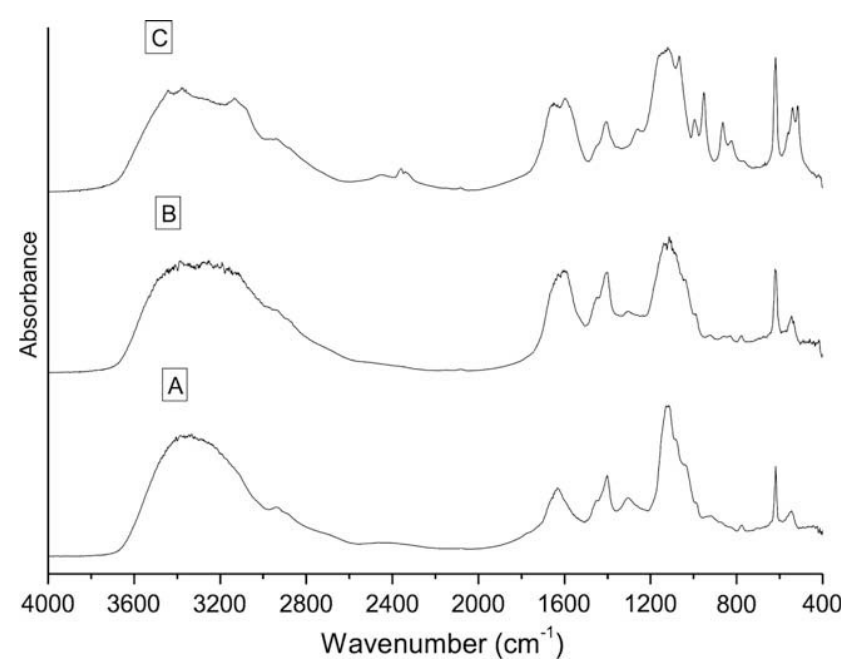

Fig. 4. FT-IR spectra of the azo dye RR198 before (A) and after microaerophilic (B) and aerobic $(C)$ treatments.

aerated, no mortality was detected for any of the dyes. The reduction in TOC under microaerophilic conditions was only $\sim 15 \%$. Conversely, a significant increase in TOC reduction (up to 88\%) was observed in the aerobic stage (Table 2).

\section{Discussion}

Staphylococcus arlettae strain VN-11 is a gram positive coccus, non-motile and facultative anaerobic bacterium. Although this bacterium has shown greater dye degradation ability as compared to other bacteria, there is no available literature on dye decolourization with Staphylococcus arlettae. Previous studies have shown that strains of Staphylococcus sp., isolated from soil in a textileeffluent treatment plant, were able to decolourize the sulfonate azo dye Congo Red (Park et al., 2005). Chen et al. (2005) isolated the gene encoding NADPH-flavin azoreductase (Azo1) from the human skin bacterium Staphylococcus aureus ATCC 25923, which confirmed that the enzyme responsible for dye decolourization could be an inducible flavoprotein using both NADH and NADPH as electron donors, as previously reported for other bacterial strains (Moutaouakkil et al., 2003). Azoreductase is the key enzyme responsible for the reductive azo dye degradation in bacterial species. The presence of oxygen normally inhibits the azo bond reduction activity, since aerobic respiration may dominate use of the NADH, thus impeding electron transfer from NADH to the azo bonds (Chang and Lin, 2001). The advantage of the anaerobic reduction of azo dyes is that oxygen depletion is easily accomplished in microaerophilic cultures thus enabling anaerobic, facultative anaerobic and microaerophilic bacteria to reduce azo dyes. The reaction takes place at neutral $\mathrm{pH}$ values and is extremely unspecific (Stolz, 2001). However, the precise mechanism of

\section{Table 2}

Mortality for Daphnia magna exposed to a 1:4 dilution of the supernatant containing azo dyes and incubated with Staphylococcus arlettae, and the \% TOC removal under static and aerobic conditions

\begin{tabular}{lllllll}
\hline \multirow{2}{*}{ Dyes } & \multicolumn{2}{l}{ Mortality $(\%)^{\mathrm{a}}$} & & \multicolumn{2}{l}{ TOC reduction $(\%)^{\mathrm{b}}$} \\
\cline { 2 - 3 } \cline { 6 - 7 } \cline { 6 - 7 } & Control & Microaerophilic & & Aerobic & Microaerophilic & Aerobic \\
\hline RY107 & 40 & 20 & 0 & 12 & 65 \\
RB5 & 40 & 30 & 0 & 17 & 62 \\
RR198 & 47 & 27 & 0 & 7 & 51 \\
DB71 & 47 & 30 & 0 & 16 & 88 \\
\hline
\end{tabular}

${ }^{\mathrm{a}} \mathrm{SD} \pm 11 \%$ for all the data.

b $\mathrm{SD} \pm 2 \%$ for all the data. anaerobic azoreduction is still not totally understood. It was recently suggested that microbial anaerobic azoreduction was linked to the electron transport chain, and that dissimilatory azoreduction was a form of microbial anaerobic respiration (Hong et al., 2007). In addition, different models for the nonspecific reduction of azo dyes by bacteria, which do not require transport of the azo dyes or reduced flavins through the cell membrane, or that describe the extracellular reduction of azo dyes by anaerobic bacteria, were recently suggested (Maier et al., 2004). These results suggested that azo dye reduction was a strain-specific mechanism that could be performed by an azoreductase enzyme or by a more complex metabolic pathway. Thus, due to the lack of information about the metabolism of Staphylococcus arlettae the usual true time dependant kinetic determinations of the azoreductase activity using the azo dye as substrate were not performed, and the azo reduction mechanism in Staphylococcus arlettae will be the subject of a future specific study.

In the present work, the strain Staphylococcus arlettae was tested to separately decolourize four azo dyes (RY107, RR198, RB5 and DB71) in a sequential microaerophilic/aerated process in the presence of yeast extract as the source of the electron donors NAD and $\mathrm{NADH}$. In the absence of yeast extract, a partial decolourization $(<50 \%)$ was achieved after $168 \mathrm{~h}$ for RY107 and RR198, but there was no decolourization for any of the dyes when the yeast extract and glucose were substituted by sodium pyruvate (data not shown). It is known that the decolourization rate of azo dyes is increased by using redox mediators such as the water-soluble flavins $\left(\mathrm{FADH}_{2}, \mathrm{FMNH}_{2}\right)$, $\mathrm{NADH}$ or NADPH, which speed up the reaction rate by shuttling electrons from the biological oxidation of primary electron donors or from bulk electron donors to the electron-accepting azo dyes (Dos Santos et al., 2004; Chang et al., 2001a; Chung and Stevens, 1993; Gingell and Walker, 1971). Thus Staphylococcus arlettae indicated the obligatory requirement of yeast extract as a redox mediator to attain efficient dye decolourization. Yeast extract, a powder supplement consisting of protein, free amino nitrogen, B vitamins, minerals, nucleotides and other yeast cell components, has been the most commonly used nitrogen source for dye decolourization processes (Robert et al., 1998). Many pure cultures like Pseudomonas luteola, Klebsiella pneumoniae and Aeromonas hydrophila have exhibited effective decolourization of different dyes in the presence of yeast extract (Hu, 1998; Chang et al., 2001b; Wong and Yuen, 1996; Chen et al., 2003; Khehra et al., 2005). Moreover, a recent study showed that a combination of the variables including glucose and yeast extract resulted in more than $90 \%$ decolourization of the azo dye Direct Black 22 (Mohana et al., 2008).

The chemical structures of the dyes greatly influence their decolourization rates, and the decolourization efficiency is limited to several azo dye structures (Chivukula and Renganathan, 1995). Dyes with simple structures and low molecular weights usually exhibit higher rates of colour removal, whereas colour removal is more difficult with highly substituted, high molecular weight dyes (Chen et al., 2003; Pearce et al., 2003). For this reason, RY107 and RR198, which are both monoazo, showed a short decolourization time (12 and $10 \mathrm{~h}$, respectively) and the highly substituted diazo RB5 and the triazo DB71 showed longer decolourization times (24 and $48 \mathrm{~h}$, respectively) (Table 1 ). It has been reported that the turnover rate of monoazo dyes increased with increasing dye concentration, whereas the turnover rate of the diazo and triazo dyes remained constant as the dye concentration increased $(\mathrm{Hu}$, 2001). Moreover, the azo compounds with a hydroxyl or amino groups were more likely to be degraded than those with methyl, methoxy, sulfo or nitro groups (Nigam et al., 1996). Usually, the presence of sulfonates in reactive dye structures results in low levels of colour removal. However, this is not applicable to direct dyes (DB71) that usually exhibit high levels of colour removal independent of the number of sulfonate groups in the dye 
structure, reinforcing the idea that steric hindrance and the number of azo bonds are responsible for the different decolourization times (Hitz et al., 1978). It has also been reported that a correlation between the enzyme redox potential and its activity towards the substrates could influence the decolourization rate (Call and Mucke, 1997; Xu et al., 1996). In this context, the decolourization times obtained in the present work were in agreement with those of Zille et al. (2004), who found a linear relationship between the cathodic peak potentials and the time of maximum decolourization for several azo dyes using an ascomycete yeast Issatchenkia occidentalis. Thus the ability of the bio-agents to degrade azo dyes depends on the structural characteristics of the dye, the temperature and the $\mathrm{pH}$ of the medium, the presence of intermediates and the difference between the redox potentials of the biocatalyst and the dye. Further studies will be carried out to measure the redox potential of the dyes by cyclic voltametry in order to verify this correlation.

The biodegradation of the azo dyes was also monitored by UVvis and FT-IR analyses (Figs. 3 and 4). Although the presence of the typical absorption peak of the hydrogenated azo bond structure $\left(\mathrm{Ar}-\mathrm{NH}-\mathrm{NH}-\mathrm{Ar}^{\prime}\right)$ at $245 \mathrm{~nm}$ in the spectra seems to indicate only partial azo bond disruption after biodegradation of the four azo dyes in the microaerophilic and aerobic treated solutions, the absorbance peaks in the visible region disappeared indicating complete decolourization (Qing, 1989). The presence of high concentrations of aromatic amines in the microaerophilic stage confirmed this statement (Table 1 ). In the UV spectra, the decrease in absorbance of the peaks at 220 and $320 \mathrm{~nm}$ corresponding, respectively, to the benzene and naphthalene rings (Yang, 1987; Mielgo et al., 2001), and the formation of a new peak at $260 \mathrm{~nm}$, suggested that the reductive destruction of the azo conjugated structure disclosed the narrow multi-peaks of aromatic rings in the spectra (Feng et al., 2000). In the FT-IR analysis, interference by the yeast extract added to the medium restricted data interpretation, showing very similar spectra. However, some conclusions were attained, and the dye (RR198), used as a model substrate, is shown in Fig. 4. The bands located within the range $1610-1630 \mathrm{~cm}^{-1}$ and at $1402 \mathrm{~cm}^{-1}$ were due to azo linkages $-\mathrm{N}=\mathrm{N}-$ on aromatic structures and of $-\mathrm{N}=\mathrm{N}$ - stretching in $\alpha$-substituted compounds, respectively (Parikh, 1974). These peaks decreased during the treatment and in some cases disappeared completely in the spectrum of the microaerophilic and aerobic treated dyes, confirming the previous UV-vis results about azo linkage disruption (Coates, 2000). In the microaerophilic stage, the reduction of the azo linkage peak was followed by the formation of two bands in the carbonyl region at around $1680-1600 \mathrm{~cm}^{-1}$. Two bands in this region were consistent with an amide derived from ammonia or a primary amine. In the aerobic stage these two bands disappeared and a new peak around $1680 \mathrm{~cm}^{-1}$ was observed. The presence of this additional group, due to the conjugation of $\mathrm{C}=\mathrm{C}$ and $\mathrm{C}=\mathrm{O}$ groups, suggested that this peak could belong to a carbonyl group in a carboxylic acid, ketone, ester or conjugated aldehyde group attached to an aromatic ring (Gavril and Hodson, 2007). The fact that no new peaks appeared between $3300-3500 \mathrm{~cm}^{-1}$ (attributed to azo bonds and $\mathrm{OH}$ groups in position $\alpha$ relative to the azo linkage) and in the region between 1340 and $1250 \mathrm{~cm}^{-1}\left(-\mathrm{NH}_{2}\right)$ after the aerobic treatment, suggested that the azo linkage could be transformed into $\mathrm{N}_{2}$ or $\mathrm{NH}_{3}$ or incorporated into the biomass (Spadaro and Renganathan, 1994; Goszczynski et al., 1994; Shaw and Freeman, 2004). Moreover, the presence of a new broad region between 2400 and $2500 \mathrm{~cm}^{-1}$ in the aerobically treated samples, could indicate the presence of carboxylic acid and $\mathrm{NH}_{3}^{+}$ions (symmetric stretching mode), suggesting partial mineralization. Also the presence of new peaks at 850 and $950 \mathrm{~cm}^{-1}$ (associated with the out-of-plane bending vibration of substituted benzenes) and the peak at $1140 \mathrm{~cm}^{-1}$ that could belong to acetate, formates, propionates, benzoates, etc., suggested that the products were undergoing irreversible chemical changes, probably due to concomitant biodegradation and autoxidation reactions of the products formed during the reductive dye degradation (Skoog et al., 1998). A large fraction of the aromatic amines from azo dyes are susceptible to autoxidation, producing water-soluble, highly coloured dimers, oligomers and eventually dark-coloured polymers with low solubility (Kudlich et al., 1999). Remarkably, in contrast to the expectation that bio-recalcitrant aromatic amines would tend to autoxidise forming coloured products, in the present experiment no increase in colour in the visible region was observed in the aerobic stage, suggesting that the aromatic amines were effectively biodegraded. However, although in some cases biodegradation of the dye's cleavage products was demonstrated (Coughlin et al., 2003), it is difficult to predict the fate of the aromatic amines during the anaerobic/aerobic treatment of azo dyes, because it is not clear whether their removal was due to biodegradation, adsorption or chemical reactions (Van Der Zee and Villaverde, 2005). The toxicity results for the controls (40-47\%), shown in Table 2, are in agreement with the findings reported by Hunger and Jung (1991) that the reactive dyes and hydrolyzed reactive dyes had a low toxic potential towards aquatic organisms as compared to the basic, acid and dispersed dye.

The Daphnia magna toxicity test demonstrated that the degradation under microaerophilic conditions was not sufficient to remove the toxicity of the samples ( $\sim 30 \%$ ). Therefore, oxidation of the aromatic amines, as confirmed by the absence of amines in the aerobic stage (Table 1 ) was necessary to diminish the toxicity in the medium. As shown in Table 2, when the medium was incubated under microaerophilic conditions, the reduction in TOC was only $\sim 15 \%$, even after 7 days of incubation. Conversely, a significant increase in TOC reduction ( $\sim 70 \%)$ was observed in the aerobic stage. It was concluded that even if the microorganisms were able to decolourize the dyes under microaerophilic conditions, the aerobic microorganisms needed aeration not only for amine removal but also for TOC stabilization (Sponza and Isik, 2005).

\section{Conclusions}

The strain VN-11 isolated from the dye effluent was identified by $16 \mathrm{~S}$ rDNA as Staphylococcus arlettae. All the dyes tested were totally and rapidly decolourized under microaerophilic conditions, with some differences in decolourization times depending on the dye structure, as confirmed by the UV-vis analysis. Decolourization was strongly dependent on the presence of yeast extract in the medium, indicating the need for additional vitamin and nitrogen sources. The formation of amines in the microaerophilic stage and their disappearance in the aerobic stage was confirmed by the direct measurement and by FT-IR analysis. In the aerobic stage the partial mineralization of the dye degradation products and of the medium metabolites, was confirmed by the FT-IR, toxicity and TOC measurements. Moreover, high decolourization efficiency was attained in the presence of only slight growth of the bacterium, which would result in very low amounts of sludge formation, thus avoiding high disposal costs. This methodology using a single microorganism in a sequential microaerophilic/aerobic process was shown to be very effective in azo dye decolourization. In a single reactor with a single bacterium, only changing the agitation conditions, it was possible not only to decolourize the dyes, but also to achieve a good degree of mineralization and low toxicity, with low running and maintenance costs.

\section{Acknowledgments}

The authors would like to thank the Portuguese Foundation of Science and Technology (FCT) for providing the grant to Andrea 
Zille (SFRH/BPD/24238 / 2005), and the Brazilian Foundation for the Coordination of the Improvement of University Graduates of the Ministry of Education (CAPES) and the National Research Counsel (CNPq) for providing the grants to Elisangela Franciscon.

\section{References}

Abadulla, E., Tzanov, T., Costa, S., Robra, K.H., Cavaco-Paulo, A., Gübitz, G.M., 2000. Decolourisation and detoxification of textile dyes with laccase from Trametes hirsuta. Applied and Environmental Microbiology 66, 3357-3362.

Ajibola, V.O., Oniye, S.J., Odeh, C.E., Olugbodi, T., Umeh, U.G., 2005. Biodegradation of Indigo containing textile effluent using some strains of bacteria. Journal of Applied Sciences 5, 853-855.

Ambrósio, S.T., Campos-Takaki, G.M., 2004. Decolorization of reactive azo dyes by Cunninghamella elegans UCP 542 under co-metabolic conditions. Bioresource Technology 91, 69-75.

Asad, S., Amoozegar, M.A., Pourbabaee, A.A., Sarbolouki, M.N., Dastgheib, S.M.M., 2007. Decolorization of textile azo dyes by newly isolated halophilic and halotolerant bacteria. Bioresource Technology 98, 2082-2088.

Abnt, NBR 12713, 1993. Água-ensaio de toxicidade aguda com Daphnia sp. (Crustacea, Cladocera). Associação Brasileira de Normas Técnicas, Rio de Janeiro, RJ, Brasil.

Blumel, S., Knackmuss, H.J., Stolz, A., 2002. Molecular cloning and characterization of the gene coding for the aerobic azoreductase from Xenoplylus azovorans KF46F. Applied and Environmental Microbiology 68, 3948-3955.

Borchert, M., Libra, J.A., 2001. Decolorization of reactive dyes by the white rot fungus Trametes versicolor in sequencing batch reactors. Biotechnology and Bioengineering 75, 313-321.

Brás, R., Ferra, I.A.F., Pinheiro, H.M., Gonslves, I.C., 2001. Batch tests for assessing decolourisation of azo dyes by methanogenic and mixed cultures. Journal of Biotechnology 89, 155-162.

Bumpus, J.A., 1995. Microbial degradation of azo dyes. In: Singh, V.P. (Ed.), Biotransformations: Microbial Degradation of Health-Risk Compounds. Elsevier Science, Amsterdam, pp. 157-175.

Bumpus, J.A., 2004. Biodegradation of azo dyes by fungi. In: Arora, D.K. (Ed.), Fungal Biotechnology in Agricultural, Food and Environmental Applications. Marcel Dekker, New York, pp. 457-480.

Call, H.P., Mucke, I., 1997. History, overview and applications of mediated lignolytic systems, especially laccase-mediator-systems (Lignozym ${ }^{\circledR}$ process). Journal of Biotechnology 53, 163-202.

Cha, C.J., Doerge, D.R., Cerniglia, C.E., 2001. Biotransformation of malachite green by fungus Cunninghamella elegans. Applied and Environmental Microbiology 67, 4358-4360.

Chagas, E.P., Durrant, L.R., 2001. Decolorization of azo dyes by Phanerochaete chrysosporium and Pleurotus sajorcaju. Enzyme and Microbial Technology 29, 473-477.

Chang, J.S., Chou, C., Lin, Y.C., Lin, P.J., Ho, J.Y., Hu, T.L., 2001a. Kinetics characteristics of bacterial azo dye decolorization by Pseudomonas luteola. Water Research 35, 2841-2850.

Chang, J.S., Chou, C., Shan-Yu, C., 2001b. Decolorization of azo dyes with immobilized Pseudomonas luteola. Process Biochemistry 36, 757-763.

Chang, J.S., Lin, C.Y., 2001. Decolorization kinetics of a recombinant Escherichia coli strain harboring azo-dye-decolorizing determinants from Rhodococcus sp. Biotechnology Letter 23, 631-636.

Chang, J.S., Lin, Y.C., 2000. Fed-batch bioreactor strategies for microbial decolorization of azo dye using a Pseudomonas luteola strain. Biotechnology Progress 16, 979-985.

Chen, H., Hopper, S.L., Cerniglia, C.E., 2005. Biochemical and molecular characterization of an azoreductase from Staphylococcus aureus, a tetrameric NADPHdependent flavoprotein. Microbiology 151, 1433-1441.

Chen, K.C., Wu, J.Y., Liou, D.J., Hwang, S.C.J., 2003. Decolorization of the textile dyes by newly isolated bacterial strains. Journal of Biotechnology 101, 57-68.

Chivukula, M., Renganathan, V., 1995. Phenolic azo dye oxidation by laccase from Pyricularia oryzae. Applied and Environmental Microbiology 61, 4374-4377.

Chung, K.T., Stevens, S.E.J., 1993. Degradation of azo dyes by environmental microorganisms and helminthes. Environmental Toxicology and Chemistry 12, $2121-2132$.

Coates, J., 2000. Interpretation of infrared spectra, a practical approach. In: Meyers, R.A. (Ed.), Encyclopedia of Analytical Chemistry. John Wiley \& Sons Ltd, Chichester, pp. 10815-10837.

Conneely, A., Smyth, W.F., McMullan, G., 1999. Metabolism of the phthalocynanine textile dye remazol turqouise blue by Phanerochaete chrysosporium. FEMS Microbiology Letters 179, 333-337.

Coughlin, M.F., Kinkle, B.K., Bishop, P.L., 2003. High performance degradation of azo dye Acid Orange 7 and sulfanilic acid in a laboratory scale reactor after seeding with cultured bacterial strains. Water Research 37, 2757-2763.

Dhanve, R.S., Shedbalkar, U.U., Jadhav, J.P., 2008. Biodegradation of diazo reactive dye Navy blue HE2R (reactive blue 172) by an isolated Exiguobacterium sp. RD3. Biotechnology and Bioprocess Engineering 13,53-60.

Do, T., Shen, J., Cawood, G., Jeckins, R., 2002. Biotreatment of textile effluent using Pseudomonas spp. immobilized on polymer supports. In: Hardin, I.R., Akin, D.E., Wilson, J. (Eds.), Advances in Biotreatment for Textile Processing. University of Georgia Press.

Dos Santos, A.B., Bisschops, I.A.E., Cervantes, F.J., Van Lier, J.B., 2004. Effect of different redox mediators during thermophilic azo dye reduction by anaerobic granular sludge and comparative study between mesophilic $\left(30^{\circ} \mathrm{C}\right)$ and thermophilic $\left(55^{\circ} \mathrm{C}\right)$ treatments for decolourisation of textile wastewaters. Chemosphere 55, 1149-1157.

Dos Santos, A.B., Cervantes, J.F., Van Lier, B.J., 2007. Review paper on current technologies for decolourisation of textile wastewaters: perspectives for anaerobic biotechnology. Bioresource Technology 98, 2369-2385.

Ewing, B., Hillier, L., Wendl, M., Green, P., 1998. Basecalling of automated sequencer traces using phred. I. Accuracy assessment. Genome Research 8, 175-185.

Fang, H., Wenrong, H., Yuezhong, L., 2004. Biodegradation mechanisms and kinetics of azo dye 4BS by a microbial consortium. Chemosphere 57, 293-301.

Feng, W., Nansheng, D., Helin, H., 2000. Degradation mechanism of azo dye C.I. reactive red 2 by iron powder reduction and photooxidation in aqueous solutions. Chemosphere 41, 1233-1238.

Field, J.A., De Jong, E., Feijoo-Costa, G., De Bont, J.A.M., 1993. Screening for ligninolytic fungi applicable to the biodegradation of xenobiotics. Trends Biotechnology 11, 44-49.

Forgacs, E., Cserhati, T., Oros, G., 2004. Removal of synthetic dyes from wastewaters: a review. Environmental International 30, 953-971.

Gavril, M., Hodson, P.V., 2007. Chemical evidence for the mechanism of the biodecoloration of Amaranth by Trametes versicolor. World Journal of Microbiology and Biotechnology 23, 103-124.

Gingell, R., Walker, R., 1971. Mechanism of azo reduction by Streptococcus faecalis. II. The role of soluble flavins. Xenobiotica 1, 231-239.

Godon, J.J., Zumstein, E., Dabert, P., Habouzit, F., Moletta, R., 1997. Molecular microbial diversity of an anaerobic digestor as determined by small-subunit rDNA sequence analysis. Applied and Environmental Microbiology 63, 2802-2813.

Gogate, P.R., Pandit, A.B., 2004a. A review of imperative technologies for wastewater treatment II: hybrid methods. Advance in Environmental Research 8, 553-597.

Gogate, P.R., Pandit, A.B., 2004b. A review of imperative technologies for wastewater treatment I: oxidation technologies at ambient conditions. Advance in Environmental Research 8, 501-551.

Goszczynski, S., Paszczynski, A., Pasti-Grisby, M.B., Crawford, R.L., 1994. New pathway for degradation of sulfonated azo dyes by microbial peroxidases of Phanerochaete chrysosporium and Streptomyces chromofuscus. Journal of Bacteriology 176, 1339-1347.

Harazono, K., Nakamura, K., 2005. Decolorization of mixtures of different reactive textile dyes by the white-rot basidiomycete Phanerochaete sordida and inhibitory effect of polyvinyl alcohol. Chemosphere 59, 63-68.

Hitz, H.R., Huber, W., Reed, R.H., 1978. The absorption of dyes on activated sludge. Journal of the Society of Dyers and Colorists 94, 71-76.

Hong, Y., Xu, M., Guo, J., Xu, Z., Chen, X., Sun, G., 2007. Respiration and growth of Shewanella decolorationis S12 with an azo compound as the sole electron acceptor. Applied and Environmental Microbiology 73, 64-72.

Hsueh, C.C., Chen, B.Y., 2008. Exploring effects of chemical structure on azo dye decolorization characteristics by Pseudomonas luteola. Journal of Hazardous Materials 154, 703-710.

Hu, T.L., 1998. Degradation of azo dye RP2B by Pseudomonas luteola. Water Science Technology 38, 299-306.

Hu, T.L., 2001. Kinetics of azoreductase and assessment of toxicity of metabolic products from azo dyes by Pseudomonas luteola. Water Science Technology 43, 261-269.

Hunger, K., Jung, R., 1991. On the toxicology and ecology of organic colorants. Chimia 45, 297-300.

Isik, M., Sponza, D.T., 2003. Aromatic amine degradation in an UASB/CSTR sequential system treating Congo Red dye. Journal of Environmental Science and Health Part A 38, 2301-2315.

Isik, M., Sponza, D.T., 2004. Monitoring of toxicity and intermediates of CI Direct Black 38 azo dye through decolorization in an anaerobic/aerobic sequential reactor system. Journal of Hazardous Materials 114, 29-39.

Kapdan, I., Kargi, F., Mcmullan, G., Marchant, R., 2000. Comparison of white rot fungi cultures for decolorization of textile dyestuffs. Bioprocess Engineering 22, 347-351.

Kapdan, I.K., Kargi, F., 2002. Biological decolorization of textile dyestuff containing wastewater by Coriolus versicolor in a rotating biological contactor. Enzyme Microbial Technology 30, 195-199.

Khalid, A., Arshad, M., Crowley, D.E., 2008. Accelerated decolorization of structurally different azo dyes by newly isolated bacterial strains. Applied Microbiology and Biotechnology 78, 361-369.

Khehra, M.S., Saini, H.S., Sharma, D.K., Chadha, B.S., Chimmi, S.S., 2005. Decolorization of various azo dyes by bacterial consortium. Dyes and Pigments 67, 55-61.

Kim, S.J., Shoda, M., 1999. Purification and characterization of a novel peroxidase from Geotrichum candidum Dec1 involved in decolorization of dyes. Applied and Environmental Microbiology 65, 1029-1035.

Kim, S.Y., Young, A.J., Woo, K.B., 2008. The effects of reductant and carbon source on the microbial decolorization of azo dyes in an anaerobic sludge process. Dyes and Pigments 76, 256-263.

Kimura, M., 1980. A simple method for estimating evolutionary rates of base substitutions through comparative studies of nucleotide sequences. Journal of Molecular Evolution 16, 111-120.

Kudlich, M., Hetheridge, M.J., Knackmuss, H.J., Stolz, A., 1999. Autoxidation reactions of different aromatic o-aminohydroxynaphthalenes that are formed during the anaerobic reduction of sulfonated azo dyes. Environmental Science \& Technology 33, 896-901.

Kudlich, M., Keck, A., Klein, J., Stolz, A., 1997. Localization of the enzyme system involved in anaerobic reduction of azo dyes by Sphingomonas sp. strain BN6 and effect of artificial redox mediators on the rate of azo dye reduction. Applied and Environmental Microbiology 63, 3691-3694. 
Kumar, S., Tamura, K., Nei, M., 2004. MEGA 3: integrated software for molecular evolutionary genetics analysis and sequence alignment. Briefings in Bioinformatics $5,150-163$.

Lane, D.J., 1991. 16S/23S rRNA sequencing. In: Stackebrandt, E., Goodfellow, M. (Eds.), Nucleic Acid Techniques in Bacterial Systematics. John Wiley \& Sons, Chichester, UK, pp. 115-175.

Libra, J.A., Borchert, M., Banit, S., 2003. Competition strategies for the decolorization of a textile-reactive dye with the white-rot fungi Trametes versicolor under nonsterile conditions. Biotechnology and Bioengineering 82, 736-744.

Lin, Y.H., Leu, J.Y., 2008. Kinetics of reactive azo-dye decolorization by Pseudomonas luteola in a biological activated carbon process. Biochemical Engineering Journal 39, 457-467.

Lodato, A., Alfieri, F., Olivieri, G., Di Donato, A., Marzocchella, A., Salatino, P., 2007. Azo-dye conversion by means of Pseudomonas sp. OX1. Enzyme and Microbial Technology 41, 646-652.

Madhavi, S., Revankar, S., Lele, S., 2007. Synthetic dye decolorization by white rot fungus, Ganoderma sp. WR-1. Bioresource Technology 98, 775-780.

Maier, J., Kandelbauer, A., Erlacher, A., Cavaco-Paulo, A., Gübitz, M.G., 2004. A new alkali-thermostable azoreductase from Bacillus sp. strain SF. Applied and Environmental Microbiology 70, 837-844.

Marik, A.S., Lam, K.S., 2003. Detection of primary aromatic amines on solid phase. Tetrahedron Letters 44, 4319-4320.

Martins, M.A.M., Queiroz, M.J., Silvestre, A.J.D., Lima, N., 2002. Relationship of chemical structures of textile dyes on the pre-adaptation medium and the potentialities of their biodegradation by Phanerochaete chrysosporium. Research Microbiology 153, 361-368.

McMullan, G., Meehan, C., Conneely, A., Kirby, N., Robinson, T., Nigam, P., Banat, I.M. Marchant, R., Smyth, W.F., 2001. Microbial decolourisation and degradation of textile dyes. Applied Microbiology and Biotechnology 56, 81-87.

Mielgo, I., Moreira, M.T., Feijoo, G., Lema, J.M., 2001. A packed-bed fungal bioreactor for continuous decolourisation of azo-dyes (Orange II). Journal of Biotechnology 89, 99-106.

Mohana, S., Shrivastava, S., Divecha, J., Madamwar, D., 2008. Response surface methodology for optimization of medium for decolorization of textile dye Direct Black 22 by a novel bacterial consortium. Bioresource Technology 99, 562-569.

Mohorcic, M., Teodorovic, S., Golob, V., Friedrich, J., 2006. Fungal and enzymatic decolourisation of artificial textile dye baths. Chemosphere 63, 1709-1717.

Moosvi, S., Keharia, H., Madamwar, D., 2005. Decolourization of textile dye Reactive Violet 5 by a newly isolated bacterial consortium RVM 11.1. World Journal of Microbiology and Biotechnology 21, 667-672.

Moutaouakkil, A., Zeroual, Y., Dzayri, Z.F., Talbi, M., Lee, K., Blaghen, M., 2003. Purification and partial characterization of azoredutase from Enterobacter agglomerans. Archives of Biochemistry and Biophysics 413, 139-146.

Nam, S., Tratnyek, P.G., 2000. Reduction of azo dyes with zero-valent iron. Water Research 34, 1837-1845.

Nigam, P., Armour, G., Banat, I.M., Singh, D., Marchant, R., 2000. Physical removal of textile dyes from effluents and solid-state fermentation of dye-adsorbed agricultural residues. Bioresource Technology 72, 219-226.

Nigam, P., Banat, I.M., Singh, D., Marchant, R., 1996. Microbial process for the decolorization of textile effluent containing azo, diazo and reactive dyes. Process Biochemistry 31, 435-442.

Olukanni, O.D., Osuntoki, A.A., Gbenle, G.O., 2006. Textile effluent biodegradation potentials of textile effluent-adapted and non-adapted bacteria. African Journal of Biotechnology 5, 1980-1984.

Ozdemir, G., Pazarbasi, B., Kocyigit, A., Omeroglu, E.E., Yasa, I., Karaboz, I., 2008 Decolorization of Acid Black 210 by Vibrio harveyi TEMS1, a newly isolated bioluminescent bacterium from Izmir Bay, Turkey. World Journal of Microbiology and Biotechnology 24, 1375-1381.

Palma, C., Moreira, M.T., Mielgo, I., Feijoo, G., Lema, J.M., 1999. Use of a fungal bioreactor as a pretreatment or post-treatment step for continuous decolorisation of dyes. Water Science Technology 40, 131-136

Pandey, A., Singh, P., Iyengar, L., 2007. Bacterial decolorization and degradation of azo dyes. International Biodeterioration and Biodegradation 59, 73-84.

Parikh, V.M., 1974. Infrared spectroscopy. In: Parikh, V.M. (Ed.), Absorption Spectroscopy of Organic Molecules. Addison-Wesley Publishing Company, Reading, MA, pp. 46-91.

Park, E.H., Jang, M.S., Cha, I.H., Choi, Y.L., Cho, Y.S., Kim, C.H., Lee, Y.C., 2005. Decolorization of a sulfonated azo dye, Congo Red, by Staphylococcus sp. EY-3. Journal of Microbiology and Biotechnology 15, 221-225.

Pasti-Grigsby, M.B., Paszczynski, A., Goszczynski, S., Crawford, D.L., Crawford, R.L., 1992. Influence of aromatic substitution patterns on azo dye degradability by Streptomyces spp. and Phanerochaete chrysosporium. Applied and Environmental Microbiology 58, 3605-3613.

Pazarlioglu, N.K., Urek, R.O., Ergun, F., 2005. Biodecolourization of Direct Blue 15 by immobilized Phanerochaete chrysosporium. Process Biochemistry 40, 1923-1929.

Pearce, C.I., Lloyd, J.R., Guthrie, J.T., 2003. The removal of colour from textile wastewater using whole bacterial cells: a review. Dyes and Pigments 58, 179-196.

Pinheiro, H.M., Touraud, E., Thomas, O., 2004. Aromatic amines from azo dye reduction: status review with emphasis on direct UV spectrophotometric detection in textile industry wastewaters. Dyes and Pigments 61,121-139.

Pitcher, D.G., Saunders, N.A., Owen, R.J., 1989. Rapid extraction of bacterial genomic DNA with guanidium thiocyanate. Letters in Applied Microbiology 8, 151-156.
Qing, C., 1989. Chemical industry. Chemistry of Dye Intermediates. Press Beijing, China, $133 \mathrm{pp}$

Rafii, F., Franklin, W., Cerniglia, C.E., 1990. Azoreductase activity of anaerobic bacteria isolated from human intestinal microflora. Applied and Environmental Microbiology 56, 2146-2151.

Robert, P., Andrew, K., Lange, J., Kirwan, D.J., 1998. Correlation of fermentation yield with yeast extract composition as characterized by near-infrared spectroscopy. Biotechnology Progress 14, 318-325.

Robinson, T., Chandran, B., Nigam, P., 2001. Studies on the production of enzymes by white-rot fungi for the decolorisation of textile dyes. Enzyme and Microbial Technology 29, 575-579.

Saitou, N., Nei, M., 1987. The neighbor-joining method: a new method for reconstructing phylogenetic trees. Molecular Biology and Evolution 4, 406-425.

Sandhya, S., Padmavathy, K., Subrahmanyam, Y.V., Kaul, N.S., 2004. Microaerophilicaerobic sequential batch reactor for treatment of azo dyes containing simulated wastewater. Process Biochemistry 40, 885-890.

Shaw, S.D., Freeman, H.S., 2004. Dyes from enzyme-mediated oxidation of aromatic amines. Textile Research Journal 74, 215-222.

Shimadzu Corporation, 1997. Instruction manual for total organic carbon analyzer model TOC-5000. Shimadzu Corp, Columbia MD, p. 7.

Sidat, M., Bux, F., Kasan, H.C., 1999. Polyphosphate accumulation by bacteria isolated from activated sludge. Water SA. http://www.wrc.org.za.

Skoog, D.A., Holler, F.J., Nieman, T.A., 1998. Principles of Instrumental Analysis, fifth ed. Harcourt Brace College Publishers, Philadelphia, pp. 404-428.

Spadaro, J.T., Renganathan, V., 1994. Peroxidase-catalysed oxidation of azo dyes: mechanism of Disperse Yellow 3 degradation. Archives of Biochemistry and Biophysics 312, 301-307.

Sponza, D.T., Isik, M., 2005. Toxicity and intermediates of CI Direct Red 28 dye through sequential anaerobic/aerobic treatment. Process Biochemistry 40 2735-2744.

Stolz, A., 2001. Basic and applied aspects in the microbial degradation of azo dyes. Applied Microbiology and Biotechnology 56, 69-80.

Supaka, N.L., Juntagjin, S., Damrobglerd, M.L., Strehaiano, D., Stephano, S., 2004. Microbial decolorization of reactive azo dyes in a sequential anaerobic/aerobic reactor system. Chemical Engineering Journal 99, 169.

Suzuki, Y., Yoda, T., Ruhul, A., Sugiura, W., 2001. Molecular cloning and characterization of the gene coding for azoreductase from Bacillus sp.0Y1-2 isolated from soil. Journal of Biological Chemistry 276, 9059-9065.

Tekere, M., Mswaka, A.Y., Zvauya, R., Read, J.S., 2001. Growth, dye degradation and ligninolytic activity studied on Zimbabwean white rot fungi. Enzyme Microbial Technology 28, 420-426.

Tetsch, L., Bend, J., Janssen, M., Holker, U., 2005. Evidence for functional laccases in the acidophilic ascomycete Hortaea acidophila and isolation of laccase-specific gene fragments. FEMS Microbiology Letters 245, 161-168.

Thompson, J.D., Higgins, D.J., Gibson, T.J., 1994. CLUSTAL W: improving the sensitivity of progressive multiple sequence alignment through sequence weighting position specific gap penalties and weight matrix choice. Nucleic Acids Research 22, 4673-4680.

Toh, Y.C., Yen, J.J.L., Obbard, J.P., Ting, Y.P., 2003. Decolourisation of azo dyes by white-rot fungi (WRF) isolated in Singapore. Enzyme and Microbial Technology $33,569-575$.

Van Der Zee, F.P., Villaverde, S., 2005. Combined anaerobic-aerobic treatment of azo dyes - a short review of bioreactor studies. Water Research 39, 1425-1440.

Vandevivere, P.C., Bianchi, R., Verstraete, W., 1998. Treatment and reuse of wastewater from the textile wet-processing industry: review of emerging technologies. Journal of Chemical Technology and Biotechnology 72, 289-302.

Verma, P., Madamwar, D., 2003. Decolourization of synthetic dyes by a newly isolated strain of Serratia marcescens. World Journal of Microbiology and Biotechnology 19, 615-618.

Vijaykumar, M.H., Vaishampayan, P.A., Shouche, S.Y., Karegoudar, T.B., 2007. Decolourization of naphthalene-containing sulfonated azo dyes by Kerstersia sp. strain VKY1. Enzyme and Microbial Technology 40, 204-211.

Wesenberg, D., Kyriakides, I., Agathos, S.N., 2003. White-rot fungi and their enzymes for the treatment of industrial dye effluents. Biotechnology Advances $22,161-187$.

Whiteley, C.G., 2007. Bioremediation of textile dyes. Industrial Bioprocessing 29, 7.

Wong, P.K., Yuen, P.Y., 1996. Decolorization and degradation of methyl red by Klebsiella pneumoniae RS 13. Water Research 30, 1736-1744.

Xu, F., Shin, W., Brown, S.H., Wahleithner, J.A., Sundaram, U.M., Solomon, E.L., 1996 A study of a series of fungal laccases and bilirubin oxidase that exhibits significant differences in redox potential, substrate specificity, and stability. Biochimica et Biophysica Acta 1292, 303-311.

Xu, M., Guo, J., Sun, G., 2007. Biodegradation of textile azo dye by Shewanella decolorationis S12 under microaerophilic conditions. Applied Microbiology and Biotechnology 76, 719-726.

Yang, J., 1987. Analysis of Dye. Chemical Industry Press, Beijing, pp. 156-163.

Zhang, F., Yu, J., 2000. Decolourisation of Acid Violet 7 with complex pellets of white rot fungus and activated carbon. Bioprocess Engineering 23, 295-301.

Zille, A., Ramalho, P., Tzanov, T., Millward, R., Aires, V., Cardoso, M.H., Ramalho, M.T. Gubitz, G.M., Cavaco-Paulo, A., 2004. Predicting dye biodegradation from redox potentials. Biotechnology Progress 20, 1588-1592.

Zollinger, H., 1991. Color Chemistry: Syntheses, Properties and Applications of Organic Dyes and Pigments, second ed. VHC Publishers, New York. 